\title{
PROFIL PENALARAN SISWA MTS DALAM MENGAJUKAN MASALAH ALJABAR DITINJAU DARI GAYA KOGNITIF VISUALISER DAN VERBALISER
}

\author{
Reski Wati S. \\ Universitas Negeri Surabaya \\ e-mail: reskiwatisalam@gmail.com
}

\begin{abstract}
Abstrak
Penelitian ini merupakan penelitian deskriptif dengan pendekatan kualitatif yang bertujuan mendeskripsikan penalaran siswa MTs dalam mengajukan masalah aljabar ditinjau dari gaya kognitif visualiser dan verbaliser. Subjek penelitian ini terdiri atas dua siswa kelas VIII di MTs Budi Dharma Surabaya yang masing-masing bergaya kognitif visualiser dan verbaliser. Instrumen pendukung dalam penelitian ini terdiri atas tes gaya kognitif, tes pengajuan masalah, dan pedoman wawancara. Berdasarkan hasil penelitian menunjukkan bahwa terdapat perbedaan penalaran siswa MTs dalam mengajukan masalah aljabar ditinjau dari gaya kognitif visualiser dan verbaliser. Pada tahap menyelesaikan masalah, siswa verbaliser mengetahui tiga metode sedangkan siswa visualiser hanya mengetahui dua metode dalam penyelesaian masalah. Selain itu pada tahap membuat masalah baru, siswa verbaliser juga memiliki lebih banyak strategi dibandingkan siswa visualiser yang hanya mengajukan masalah dengan menyusun kembali elemen dari struktur masalah asli dengan sedikit perubahan.
\end{abstract}

Kata kunci: Profil Penalaran, Pengajuan Masalah, Gaya Kognitif

\begin{abstract}
This research was a descriptive research with qualitative approach that was aimed to describe the reasoning of junior high school students' on problem posing viewed from visualizer and verbalizer cognitive style. The subject of this research was consist of two students of the second grade students at MTs Budi Dharma Surabaya with cognitive style verbalizer and visualizer. The instrument used in this research was a cognitive style test, problem posing test, and interview guidelines. Data was analyzed based on the reasoning activity which appears at the time of problem posing. Based on the results of research showing the differences in reasoning of junior high school students' on algebra problem posing viewed from visualizer and verbalizer cognitive style. When solving problems, verbaliser students know three methods while visualiser students only know two methods of problem solving. In addition, creating new problems, verbaliser students also have more strategies than visualiser students who only discuss problems by rearranging elements of the original problem structure with some change.
\end{abstract}

Keywords: Reasoning Profile, Problem Posing, Cognitive Style

\section{Pendahuluan}

Kemajuan zaman terus mengalami peningkatan yang berakibat pada meningkat pula daya saing dalam masyarakat di segala bidang. Selain itu, hal tersebut juga mengakibatkan bertambah pula permasalahan yang dihadapi manusia dalam hidupnya. Berbagai permasalahan yang dihadapi oleh manusia menuntut adanya potensi yang harus dimiliki oleh setiap manusia untuk melahirkan pemikiranpemikiran cepat, tepat dan dapat memunculkan kreativitas dalam kehidupan sehari-hari.

Pendidikan merupakan salah satu usaha sadar untuk menumbuh kembangkan kualitas sumber daya manusia yang mampu menguasai dan mengembangkan IPTEK. Dengan pendidikan, siswa 
diharapkan memiliki bekal yang mantap, baik dari segi emosional maupun dari segi intelektual dalam merespon perubahan zaman yang penuh dengan problematika kehidupan.

Matematika sebagai salah satu ilmu dasar, baik aspek terapannya maupun aspek penalarannya yang memiliki peran penting dalam upaya penguasaan ilmu pengetahuan dan teknologi. Begitu banyak pengertian tentang matematika. Secara etimologis, matematika berarti ilmu pengetahuan yang diperoleh dengan bernalar. Ditinjau dari objek yang dikaji, matematika termasuk dalam ilmu abstrak. Disebut abstrak karena terkait dengan pola-pola, bentuk, ukuran-ukuran, serta cara berfikir yang tidak dapat dilihat langsung, dipegang, diraba atau ditangkap oleh panca indra lainnya. Salah satu cara untuk memahami abstraksi adalah penalaran.

Matematika dan penalaran merupakan dua hal yang tidak dapat dipisahkan yaitu materi matematika dipahami melalui penalaran dan penalaran dipahami dan dilatih melalui belajar materi matematika. Hal itu sejalan dengan pendapat [1] yang menyatakan bahwa "Developing mathematical reasoning is central to mathematics education, it is one of the five process standarts in the Principles and Standarts for School Mathematics". Peningkatan penalaran matematika adalah inti dari pendidikan matematika yang merupakan satu dari lima proses standar pada prinsip dan standar untuk matematika sekolah.

Penalaran sangat diperlukan dalam mempelajari matematika. Seperti yang dikemukakan oleh [2] yaitu "it has long been accepted that reasoning is important in mathematics, both in learning mathematics and in doing it". Artinya sudah sekian lama disetujui bahwa penalaran sangat penting dalam matematika, baik dalam pembelajaran matematika maupun menggunakan matematika. Selain itu, [3] menegaskan bahwa penting bagi siswa untuk mempunyai kemampuan analisis, bernalar dan komunikasi secara efektif ketika mereka mengajukan, menyelesaikan dan menginterpretasi masalah dalam berbagai situasi.

National Council of Teacher of Mathematics (NCTM) juga mempublikasikan penalaran sebagai salah satu standar penting dalam pembelajaran matematika. [4] identified five process standards that are important in a mathematics program, the process standards inclued: (1) problem solving; (2) reasoning and proof; (3) communication; (4) connections; (5) interpretation. Identifikasi lima proses standar yang penting dalam pembelajaran matematika, proses standarnya termasuk: (1) penyelesaian masalah; (2) penalaran dan pembuktian; (3) komunikasi; (4) koneksi; (5) interpretasi.

Lebih lanjut, [5] mengemukakan bahwa "reasoning in mathematics is a cognitive process of looking for reasons and looking for conclusion". Penalaran pada metematika adalah sebuah proses kognitif dari pencarian alasan dan kesimpulan. Berdasarkan pemaparan di atas, jelas bahwa penalaran dalam matematika adalah suatu proses kognitif dalam mencari kesimpulan yang sangatlah penting untuk dimiliki oleh siswa.

Kenyataannya, kemampuan penalaran siswa di Indonesia masih jauh dari harapan. Keadaan tersebut dapat dilihat dari dua hasil survei internasional PISA (Programme for International Student Assessment) yang diadakan tiga tahun sekali dan TIMSS (Trends in International Mathematics and Science Study) yang diadakan empat tahun sekali. Berdasarkan hasil survei PISA menunjukkan bahwa sejak tahun 2000 sampai 2012 Indonesia selalu berada di peringkat sepuluh terbawah dari seluruh negara dan wilayah yang masuk survei PISA. Survei PISA diikuti oleh negara-negara yang bergabung dalam The Organisation for Economic Co-operasinand Development (OECD). Pada tahun 2000 tercatat sebanyak 41 negara berpartisipasi sebagai peserta sedangkan pada tahun 2003 menurun menjadi 40 negara dan pada tahun 2006 meningkat menjadi 57 negara. Pada tahun 2009dan 2012 meningkat menjadi 65 negara.

Sedangkan hasil survei TIMSS menunjukkan bahwa sejak tahun 1999 sampai 2011 Indonesia selalu berada di bawah rata-rata skor internasional. Adapun soal yang diujikan merupakan soal matematika yang menguji pengetahuan, penalaran, dan penerapan. Selain itu, dalam penelitiannya, [6] menjelaskan kesulitan-kesulitan yang dialami siswa SMP dalam menyelesaikan soal-soal matematika pada ujian nasional (UN) yaitu siswa kesulitan dalam proses, menarik kesimpulan dan ceroboh dalam 
menjawab yang mana ketiga kesulitan tersebut merupakan bagian dari penalaran. Hal ini berarti siswa masih belum maksimal menggunakan penalarannya. Padahal objek-objek yang dikaji dalam matematika bersifat abstrak sehingga siswa perlu menggunakan daya nalarnya untuk menyelesaikan soal yang diberikan.

Salah satu upaya untuk meningkatkan kemampuan penalaran siswa adalah aktivitas pengajuan masalah atau yang lebih dikenal dengan problem posing karena dengan pengajuan masalah, penalaran siswa akan terlatih melalui proses pembuatan soal oleh siswa yang diperoleh dari hasil belajar atau hasil eksperimen yang berhubungan dengan minat masing-masing siswa. Proses pemecahan masalah terletak pada diri siswa, variabel dari luar hanya merupakan instruksi yang bersifat membantu atau membimbing siswa untuk memecahkan masalah.

[7] mengemukakan pengajuan masalah merupakan salah satu jenis penalaran. Penalaranlah yang penting ketika siswa membuat atau memodelkan masalah-masalah baru berdasarkan masalah yang ada. Dengan kemampuan penalaran yang dimiliki siswa, siswa dapat berpikir membuat masalah baru. Hal tersebut disebabkan karena pengajuan masalah merupakan salah satu inti terpenting pada matematika dan dalam sifat pemikiran penalaran matematika. Tanpa penalaran, siswa tidak akan dapat mengajukan masalah yang logis dan berdasarkan fakta-fakta yang dimiliki.

Sejalan dengan pendapat tersebut, [8] pendekatan pengajuan masalah dapat membantu siswa dalam mengembangkan keyakinan dan kesukaan terhadap matematika. Pengajuan masalah juga dapat meningkatkan kemampuan matematika sebab dalam pengajuan masalah siswa perlu membaca suatu informasi yang diberikan dan mengomunikasikan pertanyaan secara verbal maupun tertulis. Selanjutnya, [9] yang mengemukakan bahwa terdapat korelasi positif antara kemampuan pengajuan masalah dengan prestasi belajar siswa. Selain itu, [10] menjelaskan pendekatan pengajuan soal dapat membantu siswa dalam mengembangkan keyakinan dan kesukaan terhadap matematika, sebab ide-ide matematika siswa dicobakan untuk memahami masalah yang sedang dikerjakan dan dapat meningkatkan performanya dalam pemecahan masalah.

[11] menyebutkan bahwa ketika siswa sendiri yang membuat suatu permasalahan, rasa kepemilikan siswa terhadap permasalahan tersebut dapat membantu meningkatkan kemampuan siswa dalam membangun pengetahuan mereka sendiri. Hasil dari rasa kepemilikan tersebut adalah tingginya rasa keingintahuan siswa. Dengan demikian pembelajaran matematika dengan pendekatan pengajuan masalah akan menambah kemampuan dan penguatan konsep dan prinsip matematika siswa.

Sejalan dengan pendapat di atas [12] menyatakan siswa yang dapat membuat soal memiliki kemampuan menyelesaikan lebih tinggi dari siswa lain. Dalam pembelajaran matematika, pengajuan masalah menempati posisi yang strategis. Pengajuan masalah dikatakan sebagai inti terpenting dalam disiplin ilmu matematika dan dalam sifat pemikiran penalaran matematika [13].

Penalaran sangat penting untuk dilatih dan ditingkatkan secara optimal dalam pembelajaran agar peserta didik dapat mengajukan masalah secara tepat dan rasional, baik untuk memahami konsep matematika maupun strategi yang digunakan untuk pembuatan masalah yang akan diajukan. Berdasarkan uraian di atas maka pengajuan masalah dan penalaran merupakan dua hal penting dan saling terkait.

Siswa dalam mengajukan masalah membutuhkan kemampuan bernalar dan kemampuan bernalar dipengaruhi oleh bagaimana siswa tersebut memperoleh, menyimpan, dan menggunakan informasi yang diterimanya [14]. Cara seseorang dalam memproses, menyimpan, maupun menggunakan informasi untuk menanggapi suatu tugas atau menanggapi berbagai jenis situasi lingkungannya disebut gaya kognitif. Gaya kognitif merupakan salah satu variabel kondisi belajar yang menjadi salah satu pertimbangan dalam merancang pembelajaran [15], Oleh sebab itu, penting untuk mengetahui gaya kognitif seseorang khususnya siswa. Tiap orang memiliki gaya kognitif yang berbeda-beda.

Terdapat beberapa jenis penggolongan gaya kognitif yang dikembangkan oleh para ahli. Diantaranya adalah gaya kognitif field dependent-field independent yang didasarkan pada pengaruh 
lingkungan terhadap aktifitas kognitif, gaya kognitif reflektif-implusif berdasarkan kecepatan dan ketepatan dalam merespon, dan gaya kognitif visualiser-verbaliser didasarkan pada perbedaan dalam mengkomunikasikan pemikiran. Diantara ketiga gaya kognitif diatas, gaya kognitif visualiser dan verbaliserlah yang paling berhubungan dengan kemampuan mengkomunikasikan pemikiran. Bernalar adalah bentuk tertinggi dari pemikiran. Oleh sebab itu gaya kognitif visualiser dan verbaliser berpengaruh terhadap kemampuan bernalar dan kemampuan bernalar berpengaruh pada perbedaan cara pengajuan masalah seseorang.

Pada penelitian ini, peneliti memilih siswa Madrasah Tsanawiyah (MTs) yang setara dengan Sekolah Menengah Pertama (SMP) sebagai subjek penelitian kerena berdasarkan usia perkembangan Piaget, pada usia ini (11 tahun-15 tahun) kemampuan berpikir siswa sudah termasuk pada tahap oprasional formal. Pada tahap oprasional formal struktur kognitif yang dimiliki siswa dapat mencapai perkembangan pada level yang lebih luas dan seorang siswa sudah memiliki kemampuan untuk menggunakan alasan berpikir logis pada semua tingkat permasalahan. Pada tahap oprasional formal ini dapat dikatakan bahwa seorang siswa sudah memiliki kemampuan berpikir abstrak, memiliki pengetahuan dasar dan pengalaman yang sesuai dengan masalah yang diberikan, dengan demikian siswa MTs/ SMP memungkinkan untuk dapat berpikir lebih fleksibel dalam memikirkan kemungkinan yang lebih banyak dalam mengajukan masalah, sehingga memudahkan untuk mengungkapkan profil penalaran siswa dalam pengajuan masalah yang diperlukan dalam penelitian ini.

Pada penelitian ini, peneliti memfokuskan pada materi Aljabar pada pokok bahasan Sistem Persamaan Linear Dua Variabel (SPLDV). Adapun dasar pemilihan materi SPLDV ialah berdasarkan hasil wawancara peneliti dengan guru bidang studi matematika di sekolah yang akan diteliti, beliau mengemukakan bahwa kebanyakan siswa sulit dalam penguasaan materi SPLDV khususnya dalam bentuk soal cerita dan hal itu berdampak terhadap penguasaan materi siswa pada materi aljabar tingkat lanjut. Selain itu SPLDV juga merupakan salah satu materi ajar yang dapat digunakan untuk melihat penalaran siswa dalam mengajukan masalah.

[16] menyatakan banyak siswa yang belum memahami konsep SPLDV dengan benar. Hal ini dikarenakan siswa belum mampu mengaitkan pengetahuan yang dimilikinya dengan pengetahuan yang akan dipelajari. NCTM (National Council of Teacher of Mathematics) [17] yaitu "algebra competance is important in adult life, both on the job and as preparation for post secondary education". Kompetensi aljabar penting untuk kehidupan mendatang, baik pada pekerjaan dan persiapan untuk pasca pendidikan menengah.

Berdasarkan penjabaran latar belakang di atas maka peneliti tertarik untuk mengkaji dan mendeskripsikan bagaimana penalaran siswa MTs dalam mengajukan masalah aljabar berdasarkan gaya kognitif visualiser dan verbaliser. Adapun tujuan penelitian ini adalah mendeskripsikan profil penalaran siswa MTs yang memiliki gaya kognitif visualiser dan verbaliser dalam mengajukan masalah aljabar

Agar tidak terdapat perbedaan penafsiran dalam memahami penelitian ini, maka beberapa istilah perlu untuk didefinisikan. Adapun istilah tersebut adalah.

a) Penalaran siswa dalam mengajukan masalah adalah aktivitas mental siswa yang meliputi mengidentifikasi situasi yang memuat masalah, memilih strategi, menerapkan strategi, dan memperoleh simpulan dalam mengajukan suatu masalah.

b) Gaya kognitif visualiser adalah siswa yang cenderung belajar dengan baik ketika menerima informasi dalam bentuk gambar-gambar atau visual, ilustrasi dan lebih menyukai permainan visual.

c) Gaya kognitif verbaliser adalah siswa yang cenderung belajar dengan baik ketika menerima informasi dalam bentuk tulisan, kata-kata dan akan lebih memilih berkomunikasi kepada seseorang dengan menunjukkan bagaimana mereka melakukannya. 


\section{Metode Penelitian}

Metode Penelitian memberikan penjelasan tentang langkah-langkah, data, lokasi penelitian, metode evaluasi yang digunakan serta penjelasan terstruktur tentang algoritma atau metode dari penelitian yang dibahas.

Jenis penelitian ini adalah deskriptif dengan pendekatan kualitatif. Menurut [18], mendefinisikan kualitatif sebagai metode penelitian yang berlandaskan pada filsafat postpositivisme, digunakan untuk meneliti pada kondisi obyek yang alamiah, (sebagai lawan adalah eksperimen) dimana peneliti adalah sebagai instrumen kunci, teknik pengumpulan data dilakukan secara triangulasi (gabungan), analisis data bersifat induktif/kualitatif, dan hasil penelitian kualitatif lebih menekankan makna dari pada generalisasi.

Subjek yang dipilih dalam penelitian ini adalah siswa Madrasah Tsanawiyah (MTs) yang memiliki gaya kognitif visualiser dan gaya kognitif verbaliser. Cara pemilihannya dengan memberikan tes penentuan gaya kognitif untuk menggolongkan siswa berdasarkan gaya kognitif. Setelah diperoleh hasil tes gaya kognitif dan tes pengajuan masalah, subjek dikelompokkan menjadi dua kelompok berdasarkan gaya kognitif dan kemampuan pengajuan masalah yaitu kelompok siswa bergaya kognitif visualiser yang dapat mengajukan masalah dan kelompok siswa bergaya kognitif verbaliser yang dapat mengajukan masalah.

Dalam penelitian ini, terdapat dua macam instrumen. Instrumen utama yaitu peneliti sendiri karena peneliti sendiri yang mengumpulkan, menganalisis dan menginterpretasi data. Sedangkan instrumen pendukung dalam penelitian ini adalah Tes Penggolongan Gaya Kognitif (TGK), Tes Pengajuan Masalah (TPS) dan Pedoman Wawancara semi terstruktur. Prosedur penelitian yang dilakukan adalah:

a) Memberikan tugas pengajuan masalah (TPM) dan tes penggolongan gaya kognitif (TKG) kepada semua siswa

b) Penetapan subjek penelitian berdasarkan hasil analisis TPM dan TKG

c) Subjek diminta untuk menyelesaikan masalah yang diberikan.

d) Subjek diwawancarai untuk mengungkap bagaimana pemahaman, proses dan konsep yang digunakan dalam menyelesaikan masalah yang diberikan.

\section{Hasil dan Pembahasan}

\section{A. Profil Penalaran Siswa MTs dalam Mengajukan Masalah Aljabar Ditinjau dari Gaya Kognitif Verbaliser}

Berdasarkan hasil penelitian, ditemukan bahwa penalaran siswa verbaliser pada tahap menyelesaikan masalah bagian mengidentifikasi situasi yang memuat masalah, siswa verbaliser mengenali informasi yang diketahui dan ditanyakan. Siswa verbaliser menyatakan kembali masalah dengan kata-katanya sendiri. Oleh sebab itu siswa verbaliser menerima informasi secara lengkap dan tepat yang termuat pada tes pengajuan masalah.

Dalam memilih strategi penyelesaian masalah, siswa verbaliser memilih strategi penyelesaian masalah menggunakan metode campuran serta menjelaskan alasan pemilihan strategi dalam menyelesaikan masalah yaitu metode campuran mudah digunakan dalam menyelesaikan masalah. Selain itu, siswa verbaliser juga dapat menyebutkan strategi lain yang dapat digunakan dalam menyelesaikan masalah yaitu menggunakan metode substitusi dan eliminasi.

Dalam menerapkan strategi, siswa verbaliser dapat menyelesaikan masalah sesuai dengan rencana yang sebelumnya telah ditentukan dan dapat menjelaskan secara sempurna setiap langkah penyelesaian. Sedangkan dalam memperoleh kesimpulan, siswa verbaliser memperoleh kesimpulan berupa solusi dari masalah yang diberikan dan dapat memastikan solusi yang diberikan sudah tepat 
dengan cara mengecek kembali seluruh langkah penyelesaian dan mensubstitusi nilai akhir yang diperoleh ke salah satu persamaan.

Pada tahap pembuatan masalah baru, bagian mengidentifikasi situasi yang memuat masalah, siswa verbaliser dapat mengidentifikasi informasi yang dimiliki dalam mengajukan masalah dan dapat menjelaskan kembali maksud dari masalah dengan kalimat sendiri. Siswa verbaliser memilih mengajukan masalah dengan cara menyusun kembali elemen dari struktur masalah asli dengan memberikan sedikit perubahan dan mengajukan masalah berdasarkan masalah yang sebelumnya pernah dikerjakan. Selain itu, siswa verbaliser juga dapat menjelaskan strategi lain yang dapat digunakan dalam mengajukan masalah yaitu memodifikasi masalah dengan mengubah yang diketahui menjadi ditanyakan.

Siswa verbaliser dapat menjelaskan langkah-langkah yang digunakan dalam mengajukan masalah. Pada soal pertama siswa verbaliser menentukan jawaban terlebih dahulu baru kemudian menyusun soal yang akan diajukan. Pada soal kedua, siswa verbaliser mengingat-ingat kembali bentuk soal yang pernah dikerjakan. Setelah mengingat, siswa verbaliser menentukan jawaban terlebih dahulu baru kemudian menyusun soal yang mirip dengan soal yang pernah dikerjakan.

Siswa verbaliser memastikan masalah yang diajukan sudah benar dengan memeriksa kembali seluruh kalimat dari masalah yang diajukan sehingga siswa verbaliser yakin masalah yang diajukan sudah benar dan mirip dengan soal yang diberikan.

Pada tahap menyelesaikan masalah, siswa verbaliser memilih menyelesaikan masalah yang diajukan dengan metode campuran yang dianggap paling mudah dan cepat. Siswa verbaliser menerapkan strategi yang dipilih yaitu menggunakan metode campuran untuk menyelesaikan masalah dan menjelaskan secara garis besar langkah-langkah yang digunakan. Siswa verbaliser memperoleh kesimpulan berupa solusi dari masalah yang diajukan dan memeriksa kembali solusi yang diperoleh dengan cara memeriksa seluruh tahap penyelesaian dan dengan mensubstitusi solusi yang diperoleh ke salah satu persamaan.

Dalam menjelaskan seluruh langkah penyelesaian masalah yang diberikan, siswa verbaliser aktif dan jelas mengungkapkan alasan-alasan pengerjaan. Hal ini sesuai dengan ciri-ciri siswa verbaliser yang dikemukakan oleh [19] yang menjelaskan bahwa seseorang yang memiliki gaya kognitif verbaliser lebih cenderung mengatakan dan akan lebih memilih untuk berkomunikasi kepada seseorang dengan menunjukkan bagaimana mereka melakukannya. Sejalan dengan pendapat tersebut, [20] menyatakan bahwa siswa dengan gaya kognitif verbaliser lebih mudah belajar dengan tulisan.

\section{B. Profil Penalaran Siswa MTs dalam Mengajukan Masalah Aljabar Ditinjau dari Gaya Kognitif Visualiser}

Berdasarkan hasil penelitian, ditemukan bahwa penalaran siswa visualiser pada tahap menyelesaikan masalah bagian mengidentifikasi situasi yang memuat masalah, siswa visualiser menjelaskan secara jelas maksud masalah dengan kata-katanya sendiri dan dapat mengungkap hal yang diketahui dan yang ditanyakan pada masalah yang diberikan. Dalam memilih strategi, siswa visualiser memilih strategi penyelesaian masalah dengan memilih metode campuran sebagai cara atau teknik yang dianggap mudah dan sering digunakan dalam menyelesaikan masalah SPLDV kemudian menyebutkan teknik lain yang dapat digunakan dalam menyelesaikan masalah yaitu metode eliminasi.

Dalam menerapkan strategi, siswa visualiser menerapkan strategi yang yang telah ditentukan untuk menyelesaikan masalah dan menjelaskan langkah-langkah yang digunakan dalam menyelesaikan masalah. Siswa visualiser memperoleh kesimpulan berupa solusi dari masalah yang diberikan dan memastikan solusi yang diberikan sudah tepat dengan cara mensubstitusi nilai akhir yang diperoleh ke salah satu persamaan. 
Pada tahap pembuatan masalah baru, bagian mengidentifikasi situasi yang memuat masalah, siswa visualiser dapat mengidentifikasi informasi yang diketahui dalam mengajukan masalah. Dalam memilih strategi, siswa visualiser mengajukan masalah dengan cara menyusun kembali elemen dari struktur masalah asli dengan memberikan sedikit perubahan. Siswa visualiser tidak dapat menyatakan strategi lain yang dapat digunakan dalam mengajukan masalah.

Dalam menerapkan strategi, siswa visualiser membuat masalah baru yang mirip dengan masalah yang diberikan yang mana dalam mengajukan masalah siswa visualiser menentukan jawaban terlebih dahulu kemudian membuat soal. Dalam memperoleh kesimpulan, siswa visualiser mengajukan dua masalah baru dan meyakini masalah yang diajukan sudah benar dengan karena telah dapat menyelesaikan masalah yang diajukan.

Pada tahap menyelesaikan masalah yang dibuat, dalam memilih strategi, siswa visualiser memilih strategi penyelesaian masalah yang diajukan dengan metode campuran yang dianggap paling mudah dan menyebutkan strategi lain yang dapat digunakan dalam menyelesaikan masalah yang diajukan. Dalam menerapkan strategi, siswa visualiser menerapkan strategi yang telah ditentukan untuk menyelesaikan masalah dengan cara menjelaskan seluruh langkah-langkah penyelesaian yang digunakan. Dalam memperoleh kesimpulan, siswa visualiser memperoleh kesimpulan berupa penyelesaian dari masalah yang diajukan dan memastikan solusi yang diberikan sudah tepat dengan mensubstitusi solusi yang diperoleh ke salah satu persamaan.

Secara umum, dari hasi pengerjaan siswa visualiser, siswa visualiser cenderung kurang teliti dalam melakukan perhitungan. Hal ini sesuai dengan pendapat [21] siswa visualiser kurang teliti dalam perhitungan dikarenakan perhitungan lebih banyak menggunakan simbol verbal, sedangkan siswa visualiser sendiri akan lebih mudah menerima informasi dalam bentuk visual.

\section{Persamaan dan Perbedaan}

Hasil analisis data dari masing-masing siswa verbaliser dan visualiser menunjukkan bahwa ada beberapa persamaan dan perbedaan penalaran siswa dalam mengajukan masalah aljabar. Berikut ini persamaan profil penalaran siswa MTs dalam mengajukan masalah aljabar ditinjau dari gaya kognitif visualiser dan verbaliser:

a) Pada tahap penyelesaian masalah, siswa senang memilih strategi penyelesaian masalah menggunakan metode campuran dibandingkan dua metode lain (metode eliminasi dan substitusi) karena metode campuran dianggap metode paliing mudah dalam menyelesaikan masalah.

b) Pada tahap mengajukan masalah baru, siswa memahami maksud dari masalah yang diberikan dan mengetahui informasi yang dimiliki dalam mengajukan masalah baru.

c) Pada tahap penyelesaian masalah, seluruh penyelesaian dari masalah yang digunakan menggunakan strategi penyelesaian yang sama yaitu menggunakan metode campuran.

Berikut ini perbedaan profil penalaran siswa MTs dalam mengajukan masalah aljabar ditinjau dari gaya kognitif visualiser dan verbaliser:

1. Tabel 1. Perbedaan Profil Penalaran Siswa MTs dalam Mengajukan Masalah Aljabar Ditinjau dari Gaya Kognitif Visualiser dan Verbaliser

\begin{tabular}{|c|c|c|c|}
\hline $\begin{array}{l}\text { Tahap } \\
\text { Mengajukan } \\
\text { Masalah }\end{array}$ & Indikator & Siswa Verbaliser & Siswa Visualiser \\
\hline $\begin{array}{c}\text { Menyelesaikan } \\
\text { masalah yang } \\
\text { diberikan }\end{array}$ & Menerapkan strategi & $\begin{array}{l}\text { Dapat menyebutkan dua strategi } \\
\text { lain yang dapat digunakan } \\
\text { dalam menyelesaikan masalah }\end{array}$ & $\begin{array}{l}\text { Hanya dapat menyebutkan } \\
\text { satu strategi lain yang dapat }\end{array}$ \\
\hline
\end{tabular}




\begin{tabular}{|c|c|c|c|}
\hline $\begin{array}{l}\text { Tahap } \\
\text { Mengajukan } \\
\text { Masalah }\end{array}$ & Indikator & Siswa Verbaliser & Siswa Visualiser \\
\hline \multirow{5}{*}{$\begin{array}{l}\text { Pembuatan } \\
\text { masalah baru }\end{array}$} & & & $\begin{array}{l}\text { digunakan dalam } \\
\text { menyelesaikan masalah. }\end{array}$ \\
\hline & $\begin{array}{l}\text { Memperoleh } \\
\text { kesimpulan }\end{array}$ & $\begin{array}{l}\text { Mengungkap kebenaran solusi } \\
\text { yang didapat dengan mengecek } \\
\text { kembali seluruh langkah } \\
\text { penyelesaian dan menunjukkan } \\
\text { cara lain dalam mengecek } \\
\text { kembali solusi yang diperoleh. }\end{array}$ & $\begin{array}{l}\text { Mengungkap kebenaran } \\
\text { solusi yang diperoleh dengan } \\
\text { menunjukkan cara dalam } \\
\text { mengecek kebenaran solusi } \\
\text { yang diperoleh }\end{array}$ \\
\hline & \multirow[t]{2}{*}{ Memilih strategi } & $\begin{array}{l}\text { Mengungkap argumen bahwa } \\
\text { strategi yang digunakan untuk } \\
\text { mengajukan masalah } \\
\text { merupakan strategi yang } \\
\text { pengajuan masalah yang mudah } \\
\text { yaitu dengan menyusun kembali } \\
\text { elemen dari struktur masalah } \\
\text { asli dengan sedikit perubahan } \\
\text { dan mengajukan masalah yang } \\
\text { sebelumnya pernah dikerjakan. }\end{array}$ & $\begin{array}{l}\text { Mengungkap argumen bahwa } \\
\text { strategi yang digunakan untuk } \\
\text { mengajukan masalah } \\
\text { merupakan strategi pengajuan } \\
\text { masalah yang paling mudah } \\
\text { yaitu dengan menyusun } \\
\text { kembali elemen dari struktur } \\
\text { masalah asli dengan sedikit } \\
\text { perubahan. }\end{array}$ \\
\hline & & $\begin{array}{l}\text { Mengungkap } \\
\text { argumen } \\
\text { mengenai strategi lain yang } \\
\text { dapat digunakan untuk } \\
\text { mengajukan masalah. }\end{array}$ & $\begin{array}{l}\text { Tidak dapat mengungkap } \\
\text { argumen mengenai strategi } \\
\text { lain yang dapat digunakan } \\
\text { untuk mengajukan masalah. }\end{array}$ \\
\hline & $\begin{array}{l}\text { Memperoleh } \\
\text { kesimpulan }\end{array}$ & $\begin{array}{l}\text { Mengungkapkan kebenaran } \\
\text { pengajuan masalah dengan } \\
\text { mengecek kebenaran kalimat } \\
\text { pada masalah yang diajukan dan } \\
\text { mencocokkan informasi yang } \\
\text { diberikan dengan masalah yang } \\
\text { diajukan. }\end{array}$ & $\begin{array}{l}\text { Meyakini kebenaran masalah } \\
\text { yang diajukan karena subjek } \\
\text { dapat membuat penyelesaian } \\
\text { dari masalah yang diajukan. }\end{array}$ \\
\hline $\begin{array}{c}\text { Menyelesaikan } \\
\text { masalah yang } \\
\text { dibuat }\end{array}$ & $\begin{array}{l}\text { Memperoleh } \\
\text { kesimpulan }\end{array}$ & $\begin{array}{l}\text { Mengungkap kebenaran solusi } \\
\text { yang didapat dengan mengecek } \\
\text { kembali seluruh langkah } \\
\text { penyelesaian yang telah } \\
\text { dikerjakan dan menunjukkan } \\
\text { cara lain dalam mengecek } \\
\text { kembali solusi yang diperoleh. }\end{array}$ & 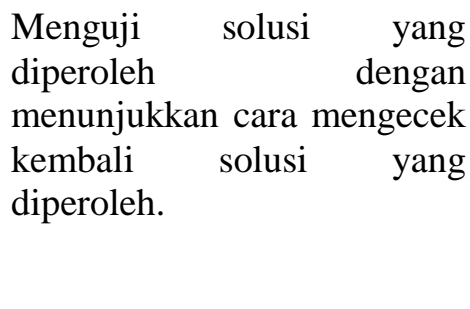 \\
\hline
\end{tabular}




\section{Kesimpulan}

Berdasarkan hasil penelitian, maka dapat disimpulan sebagai berikut:

\section{A. Profil Penalaran Siswa MTs Bergaya Kognitif Verbaliser dalam Mengajukan Masalah Aljabar}

Pada tahap menyelesaikan masalah bagian mengidentifikasi situasi yang memuat masalah, siswa verbaliser mengenali informasi yang diketahui dan ditanyakan. Siswa verbaliser menyatakan kembali masalah dengan kata-katanya sendiri. Oleh sebab itu siswa verbaliser menerima informasi secara lengkap dan tepat yang termuat pada tes pengajuan masalah. Siswa verbaliser memilih strategi penyelesaian masalah menggunakan metode campuran serta menjelaskan alasan pemilihan strategi dalam menyelesaikan masalah. Selain itu, siswa verbaliser juga dapat menyebutkan strategi lain yang dapat digunakan dalam menyelesaikan. Siswa verbaliser dapat menyelesaikan masalah sesuai dengan rencana yang sebelumnya telah ditentukan dan dapat menjelaskan secara sempurna setiap langkah penyelesaian. Siswa verbaliser memperoleh kesimpulan berupa solusi dari masalah dan dapat memastikan solusi yang diperoleh sudah tepat dengan cara mengecek kembali seluruh langkah penyelesaian dan mensubstitusi nilai akhir yang diperoleh ke salah satu persamaan.

Pada tahap pembuatan masalah baru bagian mengidentifikasi situasi yang memuat masalah, siswa verbaliser dapat mengidentifikasi informasi yang dimiliki dalam mengajukan masalah dan dapat menjelaskan kembali maksud dari masalah dengan kalimat sendiri. Siswa verbaliser memilih mengajukan masalah dengan cara menyusun kembali elemen dari struktur masalah asli dengan memberikan sedikit perubahan dan mengajukan masalah berdasarkan masalah yang sebelumnya pernah dikerjakan. Selain itu, siswa verbaliser juga dapat menjelaskan strategi lain yang dapat digunakan dalam mengajukan masalah. Siswa verbaliser dapat menjelaskan langkah-langkah yang digunakan dalam mengajukan masalah. Siswa verbaliser memastikan masalah yang diajukan sudah benar dengan memeriksa kembali seluruh kalimat dari masalah yang diajukan sehingga siswa verbaliser yakin masalah yang diajukan sudah benar dan mirip dengan soal yang diberikan.

Pada tahap menyelesaikan masalah, siswa verbaliser memilih menyelesaikan masalah yang diajukan dengan metode campuran yang. Siswa verbaliser menerapkan strategi yang dipilih yaitu menggunakan metode campuran untuk menyelesaikan masalah dan menjelaskan secara garis besar langkah-langkah yang digunakan. Siswa verbaliser memperoleh kesimpulan berupa solusi dari masalah yang diajukan dan memeriksa kembali solusi yang diperoleh dengan cara memeriksa seluruh tahap penyelesaian dan dengan mensubstitusi solusi yang diperoleh ke salah satu persamaan.

\section{B. Profil Penalaran Siswa MTs Bergaya Kognitif Visualiser dalam Mengajukan Masalah Aljabar}

Pada tahap menyelesaikan masalah bagian mengidentifikasi situasi yang memuat masalah, siswa visualiser menjelaskan secara jelas maksud masalah dengan kata-katanya sendiri dan dapat mengungkap hal yang diketahui dan yang ditanyakan pada masalah yang diberikan. Dalam memilih strategi, siswa visualiser memilih strategi penyelesaian masalah dengan memilih metode campuran kemudian menyebutkan strategi/ cara lain yang dapat digunakan dalam menyelesaikan masalah. Siswa visualiser menerapkan strategi yang yang telah ditentukan untuk menyelesaikan masalah dan menjelaskan langkah-langkah yang digunakan dalam menyelesaikan masalah. Siswa visualiser memperoleh kesimpulan berupa solusi dari masalah yang diberikan dan memastikan solusi yang diberikan sudah tepat dengan cara mensubstitusi nilai akhir yang diperoleh ke salah satu persamaan.

Pada tahap pembuatan masalah baru bagian mengidentifikasi situasi yang memuat masalah, siswa visualiser dapat mengidentifikasi informasi yang diketahui dalam mengajukan masalah. Siswa visualiser mengajukan masalah dengan cara menyusun kembali elemen dari struktur masalah asli dengan memberikan sedikit perubahan. Siswa visualiser tidak dapat 
menyatakan strategi lain yang dapat digunakan dalam mengajukan masalah. Siswa visualiser membuat masalah baru yang mirip dengan masalah yang diberikan yang mana dalam mengajukan masalah siswa visualiser menentukan jawaban terlebih dahulu kemudian membuat soal. Siswa visualiser mengajukan dua masalah baru dan meyakini masalah yang diajukan sudah benar dengan karena telah dapat menyelesaikan masalah yang diajukan.

Pada tahap menyelesaikan masalah yang dibuat, siswa visualiser memilih strategi penyelesaian masalah yang diajukan dengan metode campuran. Siswa visualiser menerapkan strategi yang telah ditentukan untuk menyelesaikan masalah dengan cara menjelaskan seluruh langkah-langkah penyelesaian yang digunakan. Siswa visualiser memperoleh kesimpulan berupa penyelesaian dari masalah yang diajukan dan memastikan solusi yang diberikan sudah tepat dengan mensubstitusi solusi yang diperoleh ke salah satu persamaan.

Penelitian ini terbatas pada penalaran siswa dalam mengajukan masalah ditinjau dari gaya kognitif visualiser dan verbaliser oleh sebab itu perlu adanya penelitian lebih lanjut terkait dengan penalaran dalam pengajuan masalah ini, karena masih banyak hal yang perlu digali tentang penalaran dalam pengajuan masalah bila dilihat dari aspek peninjauan yang lain, baik ditinjau dari kemampuan matematika, gaya belajar, jenis kelamin dan lain-lain.

\section{Daftar Pustaka}

[1] Reid, D. A. Conjectures and refuatations in Grade 5 Mathematics. Journal for Research in Mathematics Education. 2002; Vol 33, No.1, 5-29

[2] Conner, Mark. Efficacy of the Theory of Planned Behaviour : A Meta-Analytic Review. British Journal of 138 Social Psychology. 2001; 471-499: The British psychological Society.

[3] Organization for Economic Cooperation and Development (OECD). Learning for tomorrow: First results from PISA 2003. 2004

[4] NCTM. Learning and Teching Geometry, K-12. Rston, Virginia: National Council of Teachers of Mathematics. 2000

[5] Stancey, K. Mathematical Teaching and Learning to Reach Beyond the Basics. Research of Conference. University of Melbourne. 2010

[6] Meifiani, N. Analisis Kesulitan Matematika Siswa SMP Negeri Pacitan pada Ujian Nasional Tahun 2009/2010. Prosiding Jurusan Matematika Program Pascasarjana UNY. 2009

[7] Stiff, L. V., \& Curcio, F. R. Developing Mathematical Reasoning in Grades K-12. 1999 Year book. Reston. Virginia. The National Council of Teachers of Mathematics. 1999

[8] Siswono, T. Y. E. Identifikasi Proses Berpikir Kreatif Siswa dalam Pengajuan Masalah (Problem Posing) Matematika Berpadu dengan Model Walls and Creative Problem Solving (CPS). Buletin Pendidikan Matematika VI. 2004; Vol VI No.2

[9] Siswono, T.Y.E. Metode Pemberian Tugas Pengajuan Soal (Probelm Posing) dalam Pembelajaran Matematika Pokok Bahasan Perbandingan di MTs Negeri Rungkut Surabaya. Tesis Magister Pendidikan Matematika Surabaya. 1999

[10] Siswono, T. Y. E. Model Pembelajaran Matematika Berbasis Pengajuan dan Pemecahan Masalah untuk Meningkatkan Kemampuan Berfikir Kreatif. Surabaya. Unesa University Press. 2008

[11] In Woo, J. H., Lew, H. C., Park, K.S. \& Seo, D. Y.(Eds). Proceeding of the $31^{\text {st }}$ conference of the international group for the pdychology of Mathematics Education. Seoul: PME. 2007; Vol. 4 pp.193-200

[12] Silver, E.A. \& Cai, J. (1996). An Analysis of Arithmetic Problem Posing by Middle School Student. Journal for Research in Mathematics Education. 1996; Vol. 27. No. 5. November 1996, h.521-539. 
[13] Silver, E.A., Downs, J. M., Leung, S. S. \& Kenny, P. A. Posing Mathematical Problems: An Exploratory Study. Journal for Research in Mathematics Education. 1996; Vol.27. No.3 ,h. 293-309.

[14] Akay, H. The Effect of Problem Posing Oriented Analyses-II Course on the Attitudes toward Mathematical and Mathematics Self-Efficiancy of Elementary Prospective Mathematics Teacher. Australian Journal of Teacher Education Turkey. 1996; Vol. 35

[15] Joyce, B. Models of Teaching, Allyn and Bacon. Boston. 1992

[16] Joffrion, H. K. Conceptual and Procedural Understanding of Algebra Concepts in The Middle Grades. Texas. A\&M University. 2005

[17] Capraro, M. M, Chavez, R. A., Capraro, M. R. Effective Preparation for Teaching of Algebra at Primary Level. Texas. A \& M University. 2008

[18] Sugiyono. Metode Penelitian Kuantitatif, Kualitatif dan R\&D. Alfabeta. 2011

[19] Mendelson, A. L. (2004). For Whom is A Picture Worth A Thousand Words? Effects of The Visualizing Cognitive Style and Attention on Processing of News Photos. Philadelpia. 2004; Journal of Literacy Volume 24.

[20] McEwan, R.C. \& Reynolds, S. Verbalizer and Visualizer: Cognitive Style That Are Less Than Equal. Fanshawe Collage. 2007

[21] Rahmad, R. R. Proses Berpikir Mahasiswa Calon Guru dalam Pengajuan Soal Matematika Tipe Post Solution Posing Berdasarkan Kemampuan Matematikanya. (Disertasi Tidak Dipublikasikan). Universitas Negeri Suabaya. 2013

[22] Mayer, R. E. Three Facets of Visual and Verbal Leaners: Cognitive Ability, Cognitif Style, and Learning Preference. Journal of Education Psychology. 2003; Vol. 95, No.4, 833-846.

[23] Alwi, H. Kamus Besar Bahasa Indonesia. Jakarta. Departemen Pendidikan Nasional Balai Pustaka. 2005 